\title{
The effect of sucrose supplements on particle-associated carboxymethylcellulase $(E C$ 3.2.1.4) and xylanase $(E C$ 3.2.1.8) activities in cattle given grass-silage-based diet
}

\author{
BY PEKKA HUHTANEN AND HANNELE KHALILI \\ Department of Animal Husbandry, University of Helsinki, SF-00710 Helsinki, Finland
}

(Received 15 August 1990 - Accepted 28 March 199l)

\begin{abstract}
Carboxymethylcellulase (EC 3.2.1.4; CMCase) and xylanase $(E C$ 3 2.1 .8$)$ activities were assayed in rumen fluid and from microbes elosely associated either with rumen particulate material or with feed particles incubated in nylon bags in the rumen of cattle. The cattle were fitted with a permanent rumen cannula and a simple ' $T$ '-piece duodenal cannula and were given four diets in a $4 \times 4$ Latin Square experiment. The basal diet (diet $C$ ) consisted of grass silage, barley and rapeseed meal $(700,240$ and $60 \mathrm{~g} / \mathrm{kg}$ total dry matter (DM)) given at the rate of $5.3 \mathrm{~kg} / \mathrm{d}$ or supplemented with $1.0 \mathrm{~kg}$ sucrose $/ \mathrm{d}$ given twice daily (diet $S$ ), twice daily with $0.25 \mathrm{~kg}$ sodium bicarbonate/d (diet B) or as a continuous intrarumen infusion (diet I). Giving sucrose supplements decreased CMCase and xylanase activities extracted from microbes associated with rumen particulate material or feed particles incubated in nylon bags as compared with diet $\mathbf{C}$. Supplementation of the sucrose diet with sodium bicarbonate resulted in higher CMCase and xylanase activities than other sucrose diets ( $\mathrm{S}$ and I). Particle-associated CMCase and xylanase activities were found to be very sensitive in detecting differences in the rumen environment and were related to changes in cell wall digestion. The activities were highly correlated with disappearance of DM and neutral-detergent fibre from nylon bags incubated in the rumen, rumen and total digestion of cell-wall carbohydrates and rumen pool size of cell-wall carbohydrates. It was concluded that the attachment of fibrinolytic enzymes is involved in the depression of fibre digestion. Particle-associated CMCase and xylanase activities were much higher when measured from rumen particulate material than from feed particles incubated in nylon bags.
\end{abstract}

Ruminant : Sucrose supplements: Enzyme activities: Fibre digestion

The structural carbohydrates of plant cell walls are degraded and utilized by many species of rumen micro-organisms. Microscopic studies have indicated that different groups of bacteria, protozoa and fungi are associated with cell walls during degradation (Akin, 1979; Bauchop, 1980). Most (50-70\%) of the rumen bacteria are associated with feed particles (Minato et al. 1966; Faichney, 1980). The more rigid cell walls that are digested require a firm adherence before degradation (Akin \& Barton, 1983) and bacterial strains that cannot adhere produce only limited cellulolysis (Morris \& Cole, 1987). Adherent fibre-degrading bacteria can bring cell-bound enzymes into contact with the substrate, thereby ensuring effective digestion. Micro-organisms attached to feed particles may be retained in the rumen up to three times longer than those free in the liquid phase (Faichney, 1980), and are therefore able to maintain their numbers at a lower growth rate.

The population of colonizing fibre-digesting bacteria can be measured indirectly by measuring carboxymethylcellulase (EC 3.2.1.4; CMCase) activity from micro-organisms closely associated with feed particles that had been incubated in nylon bags in the rumen (Silva et al. 1987). However, the assumption that the microbial population inside the bag is the same as that in the surrounding rumen ingesta is not always valid (Meyer \& Mackie, 
1986). The attachment of hemicellulolytic bacteria has received less attention than that of cellulolytic bacteria, although the amounts of cellulose and hemicellulose in forages are almost equal. Starch and sugar supplements reduce rumen $\mathrm{pH}$ and as a result cell wall digestion is decreased, leading to reduced intake of forage. Two aspects of the negative effect of easily fermentable carbohydrates on rumen cellulolysis can be differentiated : a ' $\mathrm{pH}$ effect' and a 'carbohydrate effect' (Mould et al. 1983). The reduction in rumen cellulolysis that could not be alleviated by increasing rumen $\mathrm{pH}$ was designated the 'carbohydrate effect' and the part due to the reduced $\mathrm{pH}$ was designated the 'pH effect'. In the studies of Rooke et al. (1987) and Huhtanen (1987) a continuous supply of soluble carbohydrates depressed fibre digestion in the rumen despite optimal $\mathrm{pH}$, demonstrating the importance of the 'carbohydrate effect'. The use of sugars provides a basis for studying the effects of altering rumen environment on cell wall digestion because both the chemical composition and the amount of fibre in the diet are unchanged.

The aim of the present work was to investigate the effect of sucrose supplements on CMCase and, in particular, xylanase (EC 3.2.1.8) activity from different phases of rumen digesta, and to compare particle-associated enzyme activities inside the nylon bags with those in the surrounding ingesta. The relative importance of the ' $\mathrm{pH}$ effect' and the 'carbohydrate effect' in rumen cell wall digestion and enzyme activities were compared by altering rumen $\mathrm{pH}$ with sugar and sugar + buffer supplements, and by changing the method of supplying the sugar, i.e. twice daily feeding or continuous feeding. Particle-associated CMCase and xylanase activities were compared with in vivo values for cell wall digestion to confirm the work of Silva et al. (1987). Preliminary accounts of some of the results have been published (Huhtanen \& Khalili, 1989, 1990).

\section{MATERIALS AND METHODS}

\section{Experimental animals and diets}

Four male Friesian cattle (initial live weight 344 (SE 5.4) kg) were used, each fitted with a permanent rumen cannula and a simple ' $\mathrm{T}$ '-piece cannula in the proximal duodenum. The animals were housed individually in metabolism cages. They were fed twice daily at 07.00 and 19.00 hours. The experimental design was a $4 \times 4$ Latin Square. The control diet comprised on a dry matter $(\mathrm{DM})$ basis $(\mathrm{g} / \mathrm{kg})$ : grass silage 700 , barley 240 and rapeseed meal 60 . The three other diets were supplemented with $1.0 \mathrm{~kg}$ sucrose given twice daily (diet $\mathrm{S})$, twice daily with $0.25 \mathrm{~kg}$ sodium bicarbonate $/ \mathrm{d}$ (diet B) or as a continuous intrarumen infusion (diet I). The diet was given at the level of $5.3 \mathrm{~kg} \mathrm{DM} / \mathrm{d}$ during the first $21 \mathrm{~d}$ period. The amounts of all dietary components were increased by $25 \mathrm{~g} / \mathrm{kg}$ after each period. The average nitrogen and neutral-detergent fibre (NDF) contents of diet $\mathrm{C}$ were 28.1 and $420 \mathrm{~g} / \mathrm{kg}$ DM and of the sucrose diets 23.6 and $354 \mathrm{~g} / \mathrm{kg}$ DM respectively. A $6 \mathrm{~d}$ faecal collection and $3 \mathrm{~d}$ duodenal spot-sampling were carried out to determine rumen and total digestibility of cell-wall carbohydrates. The details of the procedures and marker techniques have been described (Huhtanen, 1988). Approximately $3 \mathrm{~g}$ DM chopped silage and milled $(2 \mathrm{~mm}$ ) hay were incubated in nylon bags (pore size $41 \mu \mathrm{m}$, external dimensions $120 \times 60 \mathrm{~mm}$ ) for determination of rumen DM and NDF degradation. The washing procedure was similar to that used for enzyme activity measurements (see p. 247). Rumen pool size of NDF was determined by manually emptying the rumen of each animal $12 \mathrm{~h}$ after the morning feed on day 21 of each period, weighing the digesta and analysing rumen contents for DM and NDF. Potentially digestible and indigestible fractions of rumen digesta and faeces were determined by incubating the samples in nylon bags in the rumen for $240 \mathrm{~h}$. The rate of digestion of cell-wall carbohydrates was calculated as described by Robinson et al. (1987). 
Table 1. The effect of diet and sampling time on carboxymethylcellulase (EC 3.2.1.4; $C M C a s e)$ and xylanase (EC 3.2.1.8) activities extracted from rumen liquid phase (RLP), strained rumen fluid ( $S R F)$ and rumen particulate material $(R P M) \dagger$ associated microbial populations of cattle given grass-silage-based diets

\begin{tabular}{|c|c|c|c|c|c|c|c|c|}
\hline & \multicolumn{4}{|c|}{ Diet $\neq$} & \multirow{2}{*}{$\begin{array}{c}\text { SEM } \\
(\mathrm{df} 6)\end{array}$} & \multicolumn{2}{|c|}{$\begin{array}{l}\text { Sampling } \\
\text { time (h) }\end{array}$} & \multirow{2}{*}{$\begin{array}{c}\text { SEM } \\
(\mathrm{df} 6)\end{array}$} \\
\hline & $\mathrm{C}$ & $\mathrm{S}$ & B & $\mathrm{I}$ & & 0 & 3 & \\
\hline \multicolumn{9}{|l|}{ RLP } \\
\hline CMCase $(\mu \mathrm{mol} / \mathrm{ml}$ per $\mathrm{min})$ & $0 \cdot 15$ & $0 \cdot 24$ & $0 \cdot 21$ & $0 \cdot 23$ & $0 \cdot 020^{*}$ & $0 \cdot 18$ & $0 \cdot 23$ & $0 \cdot 018$ \\
\hline Xylanase $(/ / \mathrm{mol} / \mathrm{ml}$ per $\mathrm{min})$ & 0.56 & 0.75 & 0.62 & $0 \cdot 70$ & 0.065 & 0.59 & 0.73 & 0.045 \\
\hline \multicolumn{9}{|l|}{ SRF } \\
\hline CMCase $(\mu \mathrm{mol} / \mathrm{ml}$ per min) & $1 \cdot 68$ & $1 \cdot 32$ & $1 \cdot 70$ & 1.67 & $0 \cdot 152$ & 1.62 & 1.57 & $0 \cdot 047$ \\
\hline Xylanase $(\mu \mathrm{mol} / \mathrm{ml}$ per $\mathrm{min})$ & $2 \cdot 53$ & 1.82 & $2 \cdot 57$ & $2 \cdot 58$ & $0.153^{*}$ & $2 \cdot 43$ & $2 \cdot 32$ & $0 \cdot 088$ \\
\hline \multicolumn{9}{|l|}{ RPM } \\
\hline CMCase $(\mu \mathrm{mol} / \mathrm{g} \mathrm{DM}$ per min) & $29 \cdot 3$ & $20 \cdot 1$ & $27 \cdot 2$ & $21 \cdot 3$ & $1 \cdot 62^{* *}$ & $26 \cdot 3$ & $22 \cdot 6$ & $0.99^{*}$ \\
\hline Xylanase ( $\mu$ mol/g DM per min) & $48 \cdot 6$ & $28 \cdot 8$ & $41 \cdot 7$ & $31 \cdot 0$ & $2 \cdot 60^{* * *}$ & $41 \cdot 3$ & $33 \cdot 7$ & $0 \cdot 70 * * *$ \\
\hline
\end{tabular}

C. basal diet; $\mathrm{S}$, basal diet supplemented with $1 \mathrm{~kg}$ sucrose/d given twice daily; B, diet $\mathrm{S}$ supplemented with $0.25 \mathrm{~kg}$ sodium bicarbonate $/ \mathrm{d}$ given twice daily; I, diet $\mathrm{S}$ given as a continuous intrarumen infusion.

$* P<0.05, * * P<0.01, * * * P<0.001$.

$\dagger$ For details, see p. 247.

For details, see p. 246.

\section{Nylon-bag incubations}

Samples of the silage given to the animals and of the hay were incubated in nylon bags in the rumen of the cattle for 12,24 and $48 \mathrm{~h}$. Silage $(210 \mathrm{~g} \mathrm{DM} / \mathrm{kg} ; 5 \mathrm{~g})$, chopped to a length of approximately $5 \mathrm{~mm}$, and $1.0 \mathrm{~g}$ milled $(2 \mathrm{~mm})$ hay were weighed into each bag. Immediately after withdrawal from the rumen the bags were washed in cold water using a household washing machine. The washing procedure lasted $30 \mathrm{~min}$ and consisted of five rinsing cycles. After the bags were washed, they were squeezed thoroughly.

\section{Rumen sampling}

Samples of rumen digesta, approximately $1 \mathrm{~kg}$, were taken from different parts of the rumen. To obtain strained rumen fluid (SRF) the samples were strained through cheesecloth. This was further centrifuged at $500 \mathrm{~g}$ for $5 \mathrm{~min}$ to obtain the rumen liquid phase (RLP). Rumen particulate matter (RPM) was placed into nylon bags and washed using a procedure similar to that used for the bags incubated in the rumen. The residue was used for enzyme assays and DM determination.

\section{Extraction of enzymes and enzyme assays}

An extraction procedure similar to that of Nossal \& Heppel (1966) was used. Undegraded feed residues (quantitatively), $2 \mathrm{~g}$ (wet weight) RPM, $5 \mathrm{ml} \mathrm{SRF}$ or $10 \mathrm{ml}$ RLP was mixed with $20 \mathrm{ml} 10 \mathrm{~mm}$-sodium phosphate buffer $(\mathrm{pH} 6.8), 2.5 \mathrm{ml}$ carbon tetrachloride and $1 \mathrm{ml}$ lysozyme solution $(50 \mathrm{mg} / \mathrm{ml})$ and incubated at $39^{\circ}$ for $3 \mathrm{~h}$. After incubation the samples were centrifuged at $26000 \mathrm{~g}$ at $4^{\circ}$ for $15 \mathrm{~min}$. The supernatant fraction was used for enzyme assays.

Hydrolysis of sodium carboxymethylcellulose (Sigma no. C-8758) and xylan (Sigma no. $\mathrm{X}$-0376) were assayed by measuring the formation of reducing sugars using 3,5dinitrosalicylic acid reagent (Fisher \& Kohtes, 1951). The procedures were described by 
Table 2. The effect of diet, type of forage and period of incubation $\dagger$ on the amount of reducing sugars produced without exogenous substrate (umol/g DM), carboxymethylcellulase (EC 3.2.1.4; CMCase) and xylanase (EC 3.2.1.8) activities extracted from feed particles incubated in nylon bags in the rumen ( $\mu \mathrm{mol} / \mathrm{g} D M$ per min)

\begin{tabular}{|c|c|c|c|c|c|c|c|c|c|c|c|c|}
\hline & \multicolumn{4}{|c|}{ Diet $_{+}^{+}$} & \multirow{2}{*}{$\begin{array}{c}\text { SEM } \\
\text { (df 6) }\end{array}$} & \multicolumn{2}{|c|}{ Forage } & \multirow{2}{*}{$\begin{array}{c}\text { SEM } \\
(\mathrm{df} 6)\end{array}$} & \multicolumn{3}{|c|}{$\begin{array}{c}\text { Period of } \\
\text { incubation }(h)\end{array}$} & \multirow{2}{*}{$\begin{array}{c}\text { SEM } \\
\text { (df 42) }\end{array}$} \\
\hline & $\mathrm{C}$ & $S$ & B & I & & Silige & Hay & & 12 & 24 & 48 & \\
\hline $\begin{array}{l}\text { Reducing sugars } \\
\text { produced without } \\
\text { exogenous substrate }\end{array}$ & $2 \cdot 28$ & $1 \cdot 70$ & $2 \cdot 35$ & 1.80 & $0.087 * * *$ & $2 \cdot 82$ & $1 \cdot 25$ & $0.056^{* * *}$ & $2 \cdot 83$ & $2 \cdot 10$ & $1 \cdot 18$ & $0 \cdot 078^{* * *}$ \\
\hline CMCase & $10 \cdot 0$ & $7 \cdot 4^{*}$ & $10 \cdot 7$ & $8 \cdot 0$ & $0 \cdot 76^{*}$ & $12 \cdot 0$ & $6 \cdot 0$ & $0.33^{* * *}$ & $6 \cdot 9$ & $9 \cdot 0$ & $11 \cdot 1$ & $0 \cdot 47^{* * *}$ \\
\hline Xylanase & 21.9 & $11 \cdot 7$ & $22 \cdot 3$ & $13 \cdot 6$ & $1 \cdot 54^{* *}$ & $20 \cdot 1$ & $14 \cdot 6$ & $0 \cdot 35^{* * *}$ & $11 \cdot 2$ & $19-1$ & $21 \cdot 8$ & $0.75^{* * *}$ \\
\hline
\end{tabular}

DM, dry matter; $C$, basal diet, $S$, basal dict supplemented with $1 \mathrm{~kg}$ sucrose/d given twice daily; $B$, diet $\mathrm{S}$ supplemented with $0.25 \mathrm{~kg}$ sodium bicarbonate given twice daily; I, diet $\mathrm{S}$ given as a continuous intrarumen infusion.

${ }^{*} P<0 \cdot 05,{ }^{* *} P<0.01,{ }^{* * *} P<0.001$.

$\dagger$ For details, see pp. 246-247.

$\ddagger$ For details, see p. 247.

Groleau \& Forsberg (1981). Before the absorbances for the xylanase assay were read, the samples were centrifuged at $800 \mathrm{~g}$ for $5 \mathrm{~min}$ to remove xylan from the incubation media.

Glucose was used as a standard for both CMCase and xylanase assays. Control assays were performed to compensate for the substrate breakdown during the extraction of enzymes. Reducing sugars produced during the enzyme extraction of undegraded feed residues and of RPM in the absence of exogenous substrate were assumed to originate from the hydrolysis of cell walls. CMCase and xylanase activities were expressed as $\mu$ mol product (glucose or xylose) released per g DM (or per $\mathrm{ml}$ ) per min under the conditions used. To calculate the amount of undegraded feed DM in nylon bags, DM disappearance was assumed to be equal to that used for DM degradation.

\section{Statistical analyses}

Enzyme activities of rumen contents were analysed by split-plot analysis of variance with sampling time being a sub-plot. Enzyme activities associated with undegraded feed residues were analysed by split-split-plot analysis of variance with type of forage being a sub-plot and period of incubation a sub-sub-plot (Gill, 1988). The sums of squares for treatment effects were further separated for orthogonal comparison of control and sucrose diets. The differences among the sucrose diets were tested by Duncan's multiple-range test. Correlation coefficients were calculated for several variables of fibre digestion and particleassociated CMCase and xylanase activities.

\section{RESULTS}

Enzyme activities extracted from rumen contents

The mean rumen $\mathrm{pH}$ was $6.28,6.03,6.24$ and 6.12 (SEM 0.061) for treatments C, S, B and I respectively. Both $\mathrm{CMCase}$ and xylanase activities were much higher in the SRF population than in the RLP population (Table 1). Sucrose supplementation increased $(P<0.05)$ CMCase activity in the liquid phase as compared with diet $C$. Xylanase activity in SRF was lower $(P<0.05)$ in cattle given diet $\mathrm{S}$ than in those given other sucrose diets. A similar trend was observed for CMCase. 
(a)

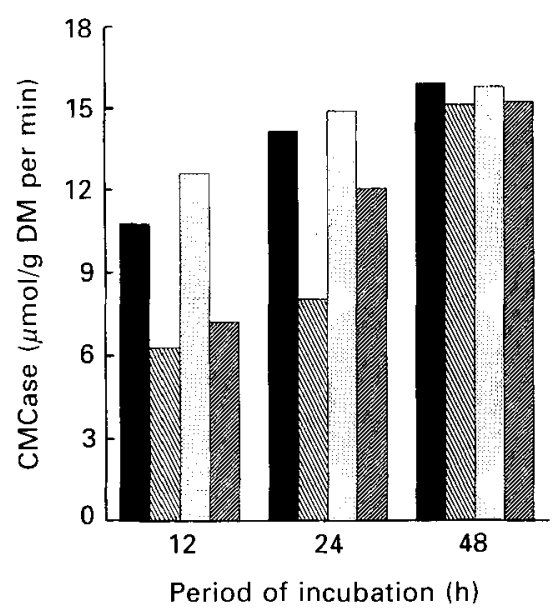

(c)

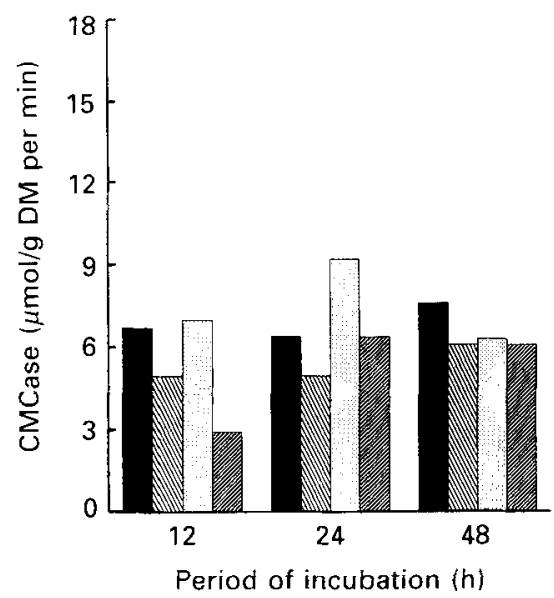

(b)

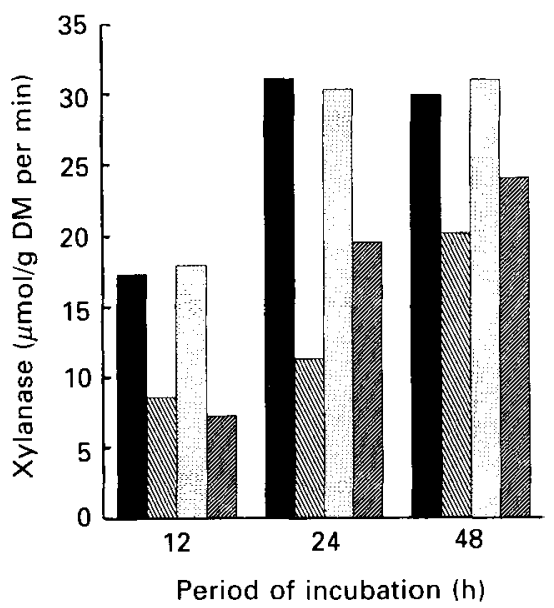

(d)

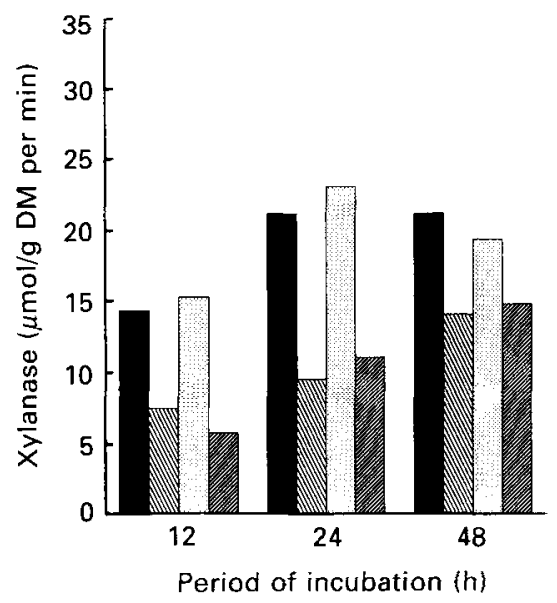

Fig. 1. The effects of sucrose supplements on carboxymethylcellulase (EC 3.2.1.4; CMCase) and xylanase (EC 3.2.1.8) activities extracted from silage ( $a$ and $b$ respectively) and hay ( $c$ and $d$ respectively) samples

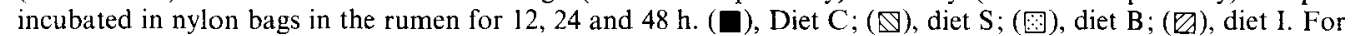
details of diets, see p. 246, and for details of procedures, see pp. 246-247. DM, dry matter.

Sucrose supplementation decreased $(P<0.01)$ the activities of particle-associated $\mathrm{CMCase}$ and xylanase. The average proportional decrease in xylanase activity was greater than that of CMCase activity $(0 \cdot 30 \% \cdot 0 \cdot 22)$. Inclusion of sodium bicarbonate in the diet increased $(P<0.05)$ both CMCase and xylanase activities as compared with diets $\mathrm{S}$ and $\mathrm{I}$. The method of giving sucrose (i.e. twice daily or as a continuous infusion) had no effect on the activities of polysaccharide-degrading enzymes. Comparison of CMCase and xylanase activities before feeding and $3 \mathrm{~h}$ after feeding indicated a trend towards an increase in RLP, whereas the activities decreased $(P<0.05)$ in RPM. Postprandial changes in the activity of particle-associated CMCase and xylanase were similar for all diets.

\section{Enzyme activities extracted from undegraded feed residues}

Sucrose supplements decreased the release of reducing sugars released without exogenous substrate during enzyme extraction and the activities of CMCase and xylanase associated 

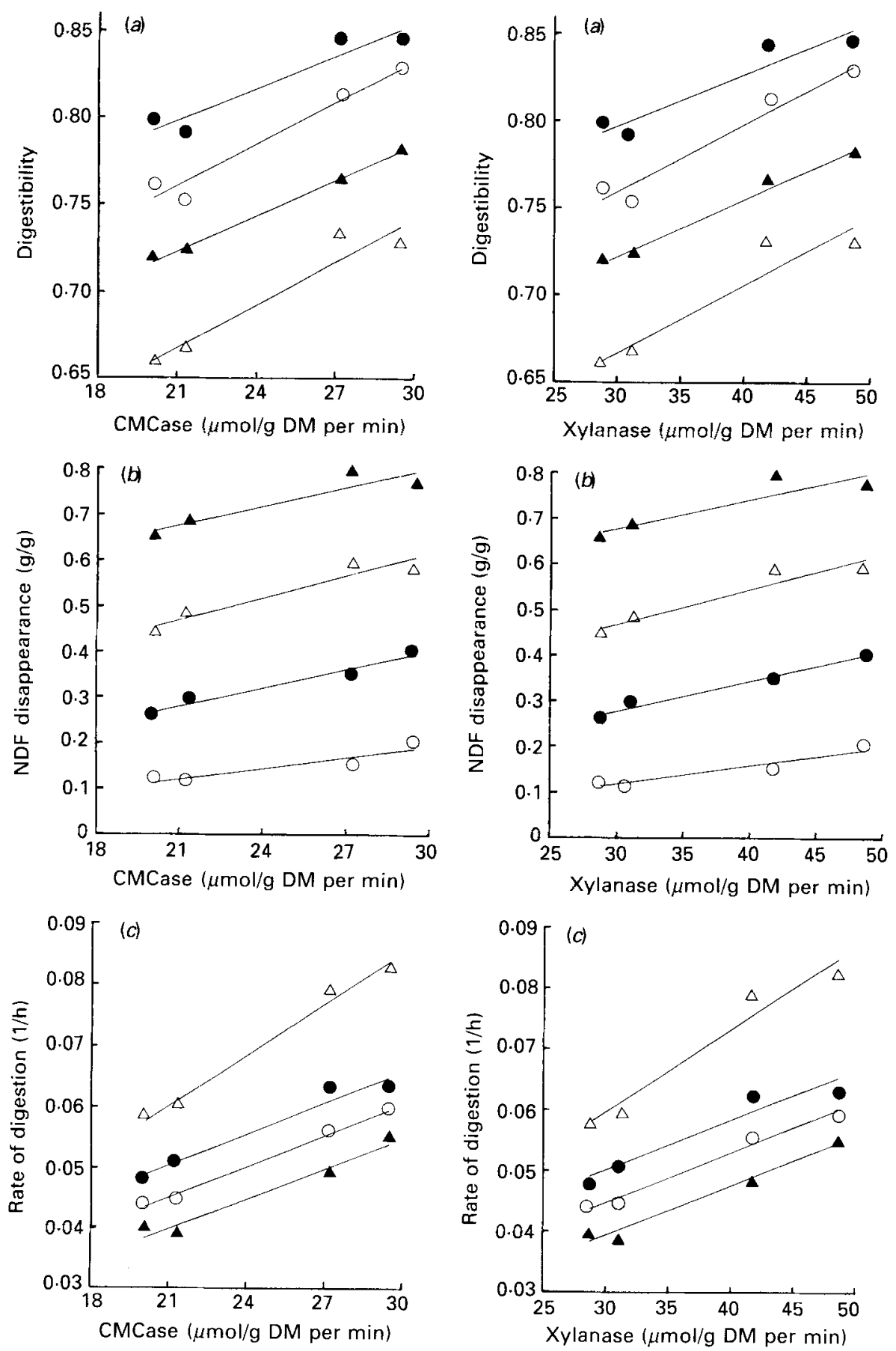

Fig. 2. Relation between carboxymethylcellulase (EC 3.2.1.4; CMCase) and xylanase (EC 3.2.1.4) activities extracted from rumen particulate material and $(a)$ rumen and total digestibility of cellulose and hemicellulose (cellulose : rumen $(O)$, total $(\boldsymbol{O})$; hemicellulose: rumen $(\triangle)$, total $(\Delta))(b)$ silage NDF disappearance from nylon bags incubated in the rumen for $6(0), 12(\boldsymbol{O}), 24(\triangle)$ and $48 \mathrm{~h}(\boldsymbol{\Delta})$ and $(\mathrm{c})$ rate of digestion of NDF $(\boldsymbol{O})$, ADF $(\bigcirc)$, cellulose $(\triangle)$ and hemicellulose $(\boldsymbol{\Delta})$. For details of procedures, see pp. 246-247. DM, dry matter. 

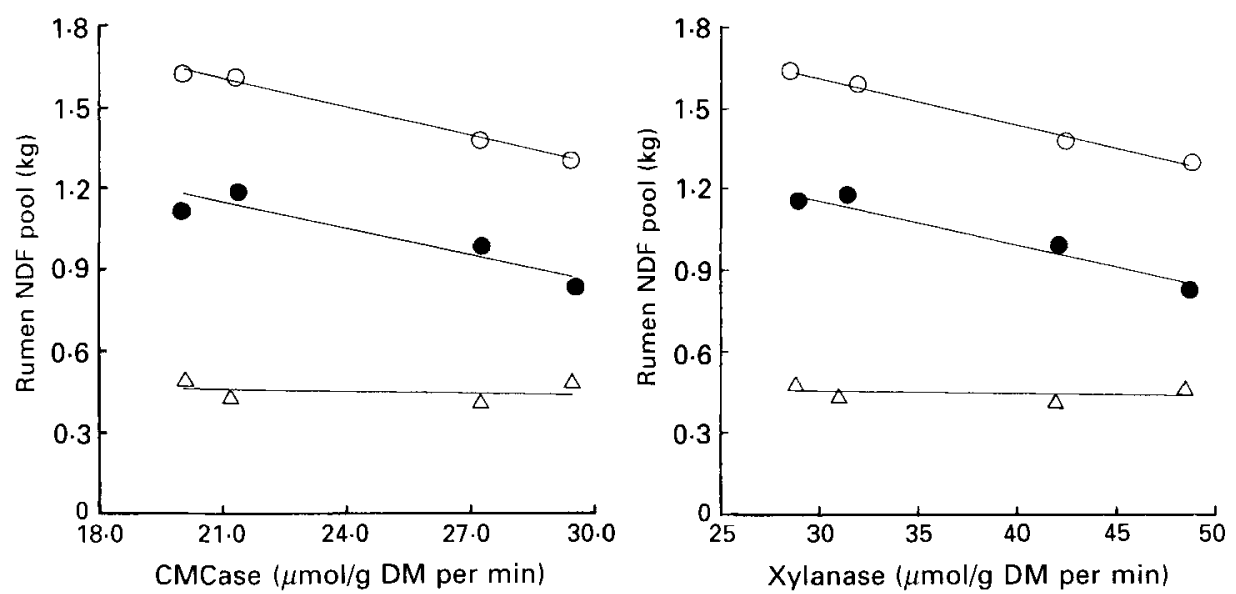

Fig. 3. Relation between carboxymethylcellulase (EC 3.2.1.4; CMCase) and xylanase (EC 3.2.1.8) activities extracted from rumen particulate material and rumen pool size of neutral-detergent fibre (NDF) (O), potentially digestible NDF $(\bigcirc)$ and indigestible NDF $(\triangle)$. For details of procedures, see pp. 246-247.

with undegraded feed residues (Table 2). The difference was significant $(P<0.05)$ for the amount of reducing sugars produced without exogenous substrate and xylanase, and approached significance $(P<0 \cdot 1)$ for CMCase. Inclusion of sodium bicarbonate increased CMCase $(P<0.05)$ and xylanase $(P<0.01)$ activities as compared with diets $\mathrm{S}$ and $\mathrm{I}$, and the values were similar to those observed with diet $C$.

The amounts of reducing sugars produced in the absence of exogenous substrate and particle-associated CMCase and xylanase activities were higher $(P<0.01)$ in silage residues than hay residues. Particle-associated enzyme activities increased $(P<0.001)$ with increasing incubation period.

The effect of the diets on the activities of CMCase and xylanase was similar when extracted either from silage or from hay residues (Fig. 1). Differences between the diets in CMCase activity diminished with increasing incubation period (diet $\times$ time interaction significant $; P<0 \cdot 05$ ).

\section{Relationship between particle-associated enzyme activity and fibre digestion}

There was a good correlation between particle-associated CMCase and xylanase activities extracted either from RPM or from feed particles incubated in nylon bags. With increasing enzyme activities rumen and total digestion of cellulose and hemicellulose increased (Fig. 2). Dietary differences in particle-associated enzyme activity were also related to a corresponding variation in NDF disappearance from nylon bags and to the rates of digestion of different cell wall components. Rumen pool size of total NDF and potentially digestible NDF were negatively correlated with enzyme activities (Fig. 3), whereas there was no correlation between indigestible NDF and enzyme activities. On the other hand, enzyme activities extracted from RLP or SRF showed no correlation with cell wall digestion.

\section{DISCUSSION}

It is generally accepted that microbial attachment to fibrous substrates is an important prerequisite of the degradation of these substrates in the rumen (Cheng et al. 1984; Morris \& Cole, 1987). The new method of using particle-associated CMCase activity to measure rapidly the colonization of fibre (Silva et al. 1987) allows the investigation of the 


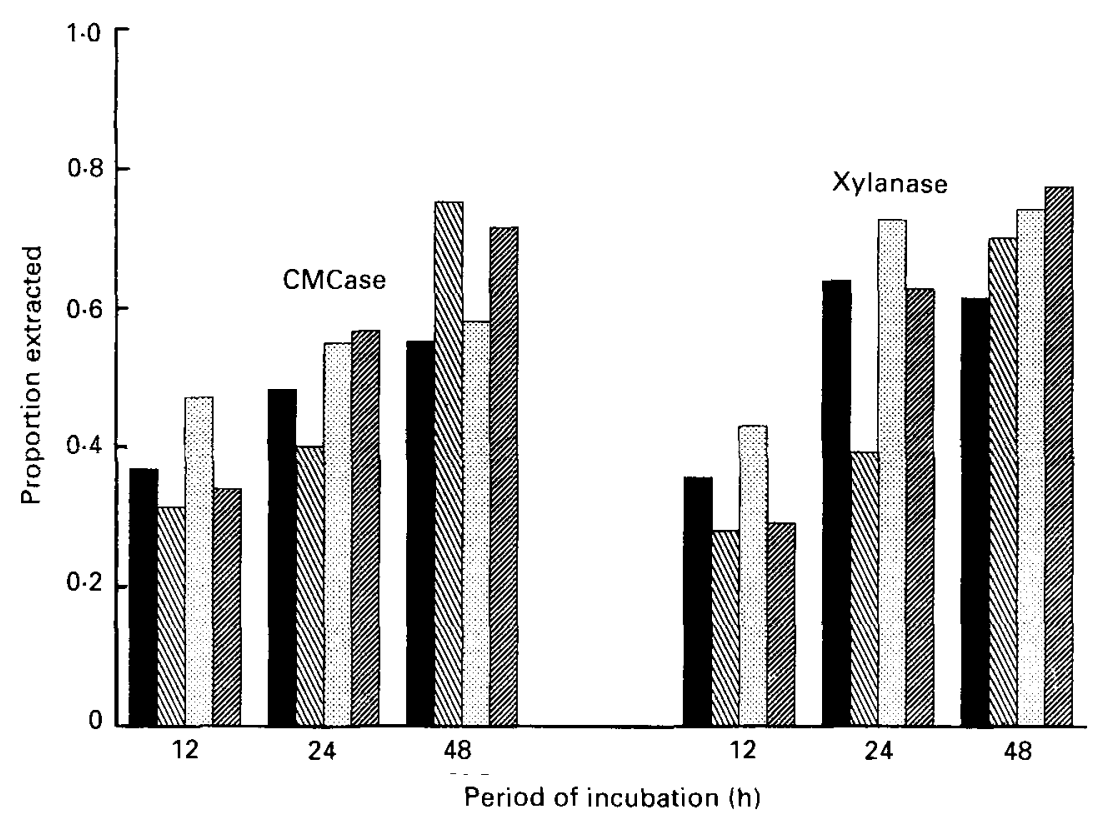

Fig. 4. The effect of dief and period of inclibation on the proportion of carboxymethylcellulase (EC 3.2.1.4; CMCase) and xylanase (EC 3.2.1.8) activities extracted from silage samples incubated in nylon bags in the

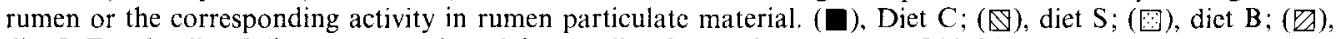
diet I. For details of diets, see p. 246 , and for details of procedures, see pp. 246-247.

relationship between microbial attachment and fibre digestion. In order to avoid the confounding effects of intrinsic characteristics and amount of fibre, sucrose supplements were used in the present experiment to produce variations in rumen environment affecting fibre digestion.

In the present study, higher CMCase activity in the RLP population with sucrose diets may indicate that cellulolytic microbes preferentially utilized soluble sugars before starting to degrade cell-wall carbohydrates (Mertens, 1977). Increased lag time of fibre digestion observed with sugar infusions (Huhtanen, 1987; Khalili \& Huhtanen, 1991) supports this concept. In agreement with Coleman (1985), CMCase activity was higher in SRF than in RLP. This would indicate either greater activity in bacteria associated with small feed particles or protozoal CMCase activity (Coleman, 1985).

Lower particle-associated CMCase and xylanase activities in animals receiving sucrose diets may be related to reduced attachment or depressed enzyme synthesis by the attached population. A similar effect of easily fermentable carbohydrates on particle-associated CMCase was also observed by Silva et al. (1987). The results presented here indicate that the adverse effect of sucrose supplements on rumen environment produced a greater depression in xylanase than in CMCase. Plant cell walls contain a variety of polymers; consequently, a complex mixture of enzymes is necessary for their hydrolysis. The high correlation between particle-associated CMCase and xylanase may indicate that the cellulolytic population also produced xylanase. Most, if not all, rumen cellulolytic bacteria can degrade hemicellulose (Dehority, 1965; Hungate, 1966).

Although differences in CMCase and xylanase activities between treatments were similar when the enzymes were extracted either from RPM or feed particles incubated in nylon bags, the activities were considerably lower in undegraded residues than in RPM (Fig. 4). This is consistent with the observations of Meyer \& Mackie (1986). In their study, even with 
the largest pore size studied $(53 \mu \mathrm{m})$ the total microbial counts within the bag were only $60 \%$ of those in the rumen digesta. This effect was even greater when cellulolytic bacteria were compared.

Several factors may contribute to this difference. The major sites for microbial attachment are cut or damaged cell wall surfaces (Latham et al. 1978; Bauchop, 1980), so the number of sites for attachment could be greater in masticated rumen digesta than in chopped silage within nylon bags. This was not, however, supported by the lower enzyme activities in hay than in silage residues. The porosity of the bags used $(41 \mu \mathrm{m})$ may prevent many of the rumen protozoa attaching to feed particles incubated in nylon bags (Ogimoto \& Imai, 1981). Moreover, the limited open surface area of the bags used (33\%) may simply prevent free inflow and outflow of the microbes as well as some essential nutrients.

The present findings support the view that reduced attachment may be involved in the depression of fibre digestion with moderate decreases in rumen $\mathrm{pH}$ (Cheng et al. 1984; Hoover, 1986). The increase in average $\mathrm{pH}$ from 6.03 to 6.24 in response to bicarbonate supplementation was accompanied by higher particle-associated CMCase and xylanase activities and improved fibre digestion. In agreement, the only effect of soluble carbohydrates on cellulose digestion in vitro appeared to be an inhibition resulting from decreased $\mathrm{pH}$ due to the rapid fermentation of carbohydrates (Hiltner \& Dehority, 1983). At low rumen $\mathrm{pH}$, hydrogen ions displace cations bound to the fibre, reducing the number of available attachment sites (McBurney et al. 1986). Almost complete alleviation of the decrease in particle-associated enzyme activities and fibre digestion in response to bicarbonate supplement suggests that the ' $\mathrm{pH}$ effect' was of greater importance in the depression of fibre digestion when sucrose was given twice daily.

The method of giving sucrose, i.e. twice daily or as a continuous infusion, had no effect on particle-associated CMCase and xylanase activities. The possible effect of the small increase in rumen $\mathrm{pH}$ in response to continuous infusion of sucrose (from 6.03 to 6.12) was probably counterbalanced by a continuous supply of soluble carbohydrates. The adverse effect of a continuous infusion of sugars on fibre digestion at an optimal rumen $\mathrm{pH}$ (Huhtanen, 1987; Rooke et al. 1987) supports the concept that the attachment of fibredegrading microbes is reduced in the presence of soluble carbohydrates. A catabolite-depression or carbon source-dependent regulation of enzyme synthesis may also explain the lower activities observed with continuous infusion of sugar. Groleau \& Forsberg (1981) observed that Bacteroides succinogenes grown on cellulose had from 7-to 8 -fold higher CMCase activity than either glucose- or cellobiose-grown cultures. Similarly, hemicellulolytic rumen bacteria grown on polysaccharide substrate produced higher hemicellulolytic activities than those grown on soluble-sugar substrate (Williams \& Withers, 1982). Therefore, it would appear that both the ' $\mathrm{pH}$ effect' and 'carbohydrate effect' were involved in the depression of CMCase and xylanase activities with continuous infusion of sucrose.

In the present study, variation in particle-associated CMCase activity was related to the corresponding variation in the degradability of silage NDF, in agreement with Silva $e t$ al. (1987). In their study, a high correlation (0.98) was seen between CMCase activity and DM degradation of ammonia-treated straw at $24 \mathrm{~h}$. In the present study, particle-associated CMCase and xylanase displayed a similar correlation with fibre digestion, indicating that both could be used as indicators of fibre digestion. Moreover, the enzyme activities were highly correlated with different measurements of in vivo fibre digestion. It appears that a reduced number of fibrinolytic bacteria is not a key factor for the depression of fibre digestion in the presence of small amounts of readily fermentable carbohydrates (Van Gylswyk \& Schwartz, 1984; Hoover, 1986). Although the dietary effects on DM degradability were rather small in the present study as compared with that of Silva et al. 
(1987), particle-associated CMCase and xylanase could assess differences in rumen environment affecting fibre digestion. As indicated by the variation in rumen pool size of NDF, particle-associated enzyme activities can detect small differences in the rate of degradation of fibrous substrates that can affect feed intake, as concluded earlier by Silva et al. (1987).

The present study demonstrates that both reduced attachment of fibrinolytic microbes to cell walls and reduction in their enzyme synthesis are involved in the depression of cell wall digestion when soluble carbohydrates are given. Lower particle-associated CMCase and xylanase activities with sucrose supplements were mainly related to reduced rumen $\mathrm{pH}$. However, when sucrose was given as a continuous infusion, the possible effect of the presence of soluble sugars could not be ruled out. Fibrinolytic activity measured as particleassociated CMCase or xylanase was a good indicator of fibre digestion with grass-silagebased diets. The lower enzyme activity in feed particles from nylon bags compared with digesta particles may indicate that the nylon bag method underestimates the rate of fibre digestion. Because physical disruption (e.g. chewing) is necessary for optimal microbial colonization, the use of RPM in assessing the effects of dietary factors on particleassociated CMCase and xylanase activity is recommended.

The authors thank the Finnish Academy for financial support and Ms Leena Laitinen, Ms Minna Honkonen and Mr J. Suomi for the technical assistance. They also thank Mr M. Tala for surgery of the experimental animals.

\section{REFERENCES}

Akin, D. E. (1979). Microscopic evaluation of forage digestion by rumen microorganisms: a review. Joumal of Animal Science 48, 701-710.

Akin, E. E. \& Barton, F. E. (1983). Rumen microbial attachment and degradation of plant cell walls. Federation Proceedings 42, 114-121.

Bauchop, T. (1980). Scanning electron microscopy in the study of plant fragments in the gut. In Contemporary Microbial Ecology, pp. 305-325 [D. C. Ellwood, J. N. Hedger, M. J. Latham, J. M. Lynch and J. H. Slater, editors]. London: Academic Press.

Cheng, K. J., Stewart, C. S., Dinsdale, D. \& Costerton, J. W. (1984). Electron microscopy of bacteria involved in the digestion of plant cell walls. Animal Feed Science and Technology 10, 93-120.

Coleman, G. S. (1985). The cellulase content of 15 species of entodiniomorphid protozoa, mixed bacteria and plant debris isolated from ovine rumen. Joumal of Agricultural Science, Cambridge 104, 349-360.

Dehority, B. A. (1965). Degradation and utilization of isolated hemicellulose by pure cultures of cellulolytic bacteria. Journal of Bacteriology 89, 1515-1520.

Faichney, G. J. (1980). Measurement in sheep of the quantity and composition of rumen digesta and fractional outflow rates of digesta constituents. Australian Journal of Agricultural Research 31, 1129-1137.

Fisher, E. H. \& Kohtes, L. (1951). Purification de l'invertase de levure. (Purification of yeast invertase.) Helvetica Chimica Acta 34, 1123-1131.

Gill, J. L. (1988). Standard errors for split-split-plot experiments with repeated measurements. Journal of Animal Breeding and Genetics 105, 329-336.

Groleau, D. \& Forsberg, C. W. (1981). Cellulolytic activity of the rumen bacterium. Bacteroides succinogenes. Canadian Journal of Microbiology 27, 517-530.

Hiltner, P. \& Dehority, B. A. (1983). Effect of soluble carbohydrates on digestion of cellulose by pure cultures of rumen bacteria. Applied and Environmental Microbiology 46, 642-648.

Hoover, W. H. (1986). Chemical factors involved in ruminal fiber digestion. Journal of Dairy Science 69 , 27552766 .

Huhtanen, P. (1987). The effects of intraruminal infusions of sucrose and xylose on the nitrogen and fibre digestion in cattle receiving diets of grass silage and barley. Journal of Agricultural Science in Finland 59, 405-423.

Huhtanen, P. (1988). The effects of supplementation of silage diet with barley, unmolassed sugar beet pulp and molasses on organic matter, nitrogen and fibre digestion in the rumen of cattle. Animal Feed Science and Technology 20, 259-278.

Huhtanen, P. \& Khalili, H. (1989). Microbial polysaccharidase activities associated with rumen particulate material and feed particles incubated in nylon bags in the rumen. Asian Australasian Journal of Animal Sciences 2, 400-401.

Huhtanen, P. \& Khalili, H. (1990). The effect of sucrose supplements on microbial polysaccharidase activities 
associated with rumen particulate material. In The Rumen Ecosystem. The Microbial Metabolism and its Regulation, pp. 121-128. [S. Hoshino, R. Onodera, H. Minato and H. Itabashi, editors]. Tokyo: Japan Scientific Societies Press.

Hungate, R. E. (1966). Rumen and its Microbes. New York: Academic Press.

Khalili, H. \& Huhtanen, P. (1991). Sucrose supplements in cattle given grass silage based diets. 2. Digestion of cell wall carbohydrates. Animal Feed Science and Technology 33, 263-273.

Latham, M. J., Brooker, B. E., Pettipher, G. L. \& Harris, P. J. (1978). Adhesion of Bacteroides succinogenes in pure culture and in the presence of Ruminococcus flavefaciens to cell walls in leaves of perennial ryegrass (Lolium perenne). Applied and Environmental Microbiology 35, $1166-1173$.

McBurney, M. I., Allen, M. S. \& van Soest, P. J. (1986). Praseodynium, and copper-exchange capacities of neutral-detergent fibres relative to composition and fermentation kinetics. Journal of the Science of Food and Agriculture 39. 666672.

Mertens, D. R. (1977). Dietary fiber components: relationship to the rate and extent of ruminal digestion. Federation Proceedings 36, 187- 192.

Meyer, J. H. \& Mackie, R. I. (1986). Microbial evaluation of the intraruminal in sacculus technique. Applied and Environmental Microbiology 51, 622-629.

Minato. H., Endo, A., Oomoto, Y. \& Uemura, T. (1966). Ecological treatise on the rumen fermentation. 2. The amylolytic and cellulolytic activities of the fractioned portions of attached to rumen solids. Journal of General and Applied Microbiology 12, 53-69.

Morris, J. \& Cole, O. J. (1987). Relationship between cellulolytic activity and adhesion to cellulose in Ruminococcus albas, Journal of General Microbiology 133, 53-69.

Mould, F. L., Ørskov, E. R. \& Mann, S. O. (1983). Associative effects of mixed feeds. I. Effect of type and level of supplementation and the infuence of rumen fluid $\mathrm{pH}$ on cellulolysis in vivo and dry matter digestion of various roughages. Animal Feed Science and Technology 10, 15-30.

Nossal, N. G. \& Heppel, L. A. (1966). Release of enzymes by osmotic shock from Escherichia coli in exponential phase. Journal of Biological Chemistry 24, 3055-3062.

Ogimoto, K. \& Imai, S. (1981). Atlas of Rumen Microbiology, pp. 231. Tokyo: Japan Scientific Societies Press.

Robinson, P. H., Tamminga, S. \& van Vuuren, A. M. (1987). Influence of declining level of starch in the concentrate on rumen ingesta quantity, composition and kinetics of ingesta turnover in dairy cows. Livestock Production Science 17, 37-62.

Rooke, J. A., Lee, N. H. \& Armstrong, D. G. (1987). The effects of intraruminal infusions of urea, casein, glucose syrup and a mixture of casein and glucose syrup on nitrogen digestion in the rumen of cattle receiving grass silage diets. British Journal of Nutrition 57, 89-98.

Silva, A. T., Wallace, R. J. \& Ørskov, E. R. (1987). Use of particle-bound microbial activity to predict the rate and extent of fibre degradation in the rumen. British Journal of Nutrition 57, 407-415.

Van Gylswyk, N. O. \& Schwartz, H. M. (1984). Microbial ecology of the rumen of animals fed high-fibre diets. In Herbivore Nutrition in the Subtropics and Tropics, pp. 359-377 [F. M. Gilchrist and R. I. Mackie, editors]. Graighall, South Africa: The Science Press.

Williams, A. G. \& Withers, S. E. (1982). The production of plant cell wall polysaccharide-degrading enzymes by rumen isolates grown on a range of carbohydrate substrates. Journal of Applied Bacteriology 52, $377-387$. 